\title{
RECEPCJA CREDO NICEJSKIEGO W NAUCZANIU SYNODALNYM KOŚCIOŁA ZACHODNIEGO IV WIEKU
}

Współczesne opracowania patrystyczne poświęcone credo nicejskiemu skupiają się najczęściej na kwestiach związanych z teologią nicejską i ariańską, względnie na zagadnieniach terminologicznych i politycznych, zasadniczo związanych z Kościołem wschodnim ${ }^{1}$. Natomiast zagadnienie odbioru credo nicejskiego w Kościele zachodnim w IV wieku najczęściej było ujmowanie pobieżnie i doczekało się niewielu prac szczegółowych, do których należą studia poświęcone działalności Hilarego z Poitiers i opozycji biskupów zachodnich wobec proariańskiej polityki dynastii Konstantynów ${ }^{2}$ czy propagowania nicejskich terminów

1 Por. M. Simonetti, La crisi ariana nel IV secolo, Roma 1975 (Studia Ephemeridis Augustinianum [dalej: SEA], 11); R. Williams, Arius: heresy and tradition, Grand Rapids 2002; J. Behr, The Nicene faith: formation of Christian theology, vol. 2, New York 2004; M. Simonetti, Studi di cristologia postnicena, Roma 2006 (SEA 98); Arianism: historical and theological reassessments: papers from the Ninth International Conference on Patristic Studies, September 5-10, 1983, Oxford, England, Eugene 2006; R. P. C. Hanson, The search for the Christian doctrine of God. The arian controversy, Grand Rapids 2007; K. Anatolis, Retrieving Nicaea: the development and meaning of trinitarian doctrine, Grand Rapids 2011; H. Pietras, Sobór nicejski (325). Kontekst religijny i polityczny, dokumenty, komentarze, Kraków 2013.

2 C. F. A. Borchardt, Hilary of Poitiers' role in the Arian struggle, Hague 1966 (Kerkhistorische Studien Behorende bij het Nederlands Archief voor Kerkgeschiedenis, 12); H. Ch. Brennecke, Hilarius von Poitiers und die Bischofsopposition gegen Konstantius II: Untersuchungen zur dritten Phase des Arianischen Streites (337-361), Berlin 1984 (Pa- 
teologicznych ${ }^{3}$. Dlatego pragnę przyjrzeć się recepcji credo nicejskiego w oficjalnym nauczaniu kościelnym na Zachodzie w IV wieku. Najpierw przedstawię recepcję credo nicejskiego w Kościele wschodnim, by w kolejnym paragrafie ukazać odbiór symbolu nicejskiego w nauczaniu synodalnym Kościoła zachodniego w latach 325-399.

\section{Recepcja credo Soboru Nicejskiego I na Wschodzie}

\section{Tekst credo Soboru Nicejskiego I z 325 roku znany jest też jako „Wy- znanie wiary 318 Ojców":}

\begin{tabular}{|c|c|}
\hline Ек $\theta \varepsilon \sigma \iota \varsigma, \tau \tilde{\omega} \nu \tau \tau v^{\prime} \pi \alpha \tau \dot{\varepsilon} \rho \omega \nu$ & „Wyznanie wiary 318 Ojców” \\
\hline 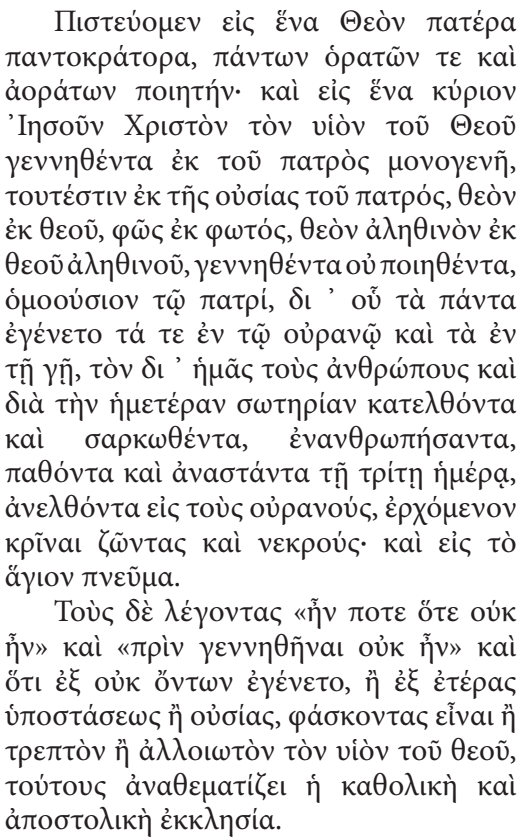 & $\begin{array}{l}\text { Wierzymy w jednego Boga Ojca } \\
\text { Wszechmogącego, Stworzyciela wszyst- } \\
\text { kich rzeczy widzialnych i niewidzialnych. } \\
\text { I w jednego Pana Jezusa Chrystusa, Sy- } \\
\text { na Bożego, zrodzonego z Ojca, jednoro- } \\
\text { dzonego, to jest z istoty Ojca, Boga z Bo- } \\
\text { ga, Światłość ze Światłości, Boga prawdzi- } \\
\text { wego z Boga prawdziwego, zrodzonego, } \\
\text { a nie uczynionego, współistotnego Oj- } \\
\text { cu, przez którego wszystko się stało, co } \\
\text { jest w niebie i co jest na ziemi, który dla } \\
\text { nas ludzi i dla naszego zbawienia zstąpił } \\
\text { i przyjął ciało, stał się człowiekiem, cier- } \\
\text { piał i zmartwychwstał trzeciego dnia, } \\
\text { wstąpił do nieba, przyjdzie sądzić żywych } \\
\text { i umarłych. I w Ducha Świętego. } \\
\text { Tych, którzy mówią: „był kiedyś } \\
\text { czas kiedy go nie było" lub „zanim się } \\
\text { narodził nie był” lub „stał się z nicze- } \\
\text { go” lub pochodzi z innej hipostazy, lub } \\
\text { z innej substancji [niż Ojciec], lub że } \\
\text { Syn Boży jest zmienny i przeobrażany, } \\
\text { tych wszystkich powszechny i apostol- } \\
\text { ski Kościół wyłącza. }\end{array}$ \\
\hline
\end{tabular}

Tekst grecki, łaciński i tłumaczenie polskie (T. Wnętrzak) za: Dokumenty Soborów Powszechnych, t. 1, red. A. Baron, H. Pietras, Kraków 2001, s. 24-25 (Źródła Myśli Teologicznej, 24).

tristische Texte und Studien, 26); D. H. Williams, The anti-Arian campaigns of Hilary of Poitiers and the 'Liber Contra Auxentium', „Church History” 1992 nr 1 (61), s. 7-22.

3 J. Ulrich, Die Anfänge der Abendländischen Rezeption des Nizänums, Berlin 1994 (Patristische Texte und Studien, 39). 
Do śmierci cesarza Konstantyna I (zm. w 337 roku) credo nicejskie było oficjalną formułą wiary chrześcijańskiej ${ }^{4}$, prawdopodobnie wpisaną do cesarskiego liber pontificalis ${ }^{5}$. Tekst wyznania w Kościele na Wschodzie został poświadczony najpierw przez Euzebiusza z Cezarei w liście do jego Kościoła ${ }^{6}$, napisanym prawdopodobnie jeszcze w 325 roku, krótko po zakończeniu obrad w Nicei. Drugim chronologicznie świadkiem powołania się na tekst credo nicejskiego był list Atanazego z Aleksandrii do bezimiennego biskupa, w którym Atanazy wyjaśniał swoje rozumienie podstaw wiary nicejskiej (credo sformułowane przeciwko arianom, punkty $2-5,5-18$ ) oraz sformułowania użyte w credo nicejskim (punkty 19-32)7. Pismo patriarchy Aleksandrii powstało między 345 a 359 rokiem $^{8}$, czyli już od 20 do 39 lat po zakończeniu obrad cesarskiego concilium w Nicei. Właśnie to pismo i ta umowna data (około 350 roku) stanowiłyby punkt zwrotny w rozpoczęciu promowania credo nicejskiego. Nie istnieją żadne dokumenty, które świadczyłyby o jego stosowaniu w jakimkolwiek Kościele partykularnym w latach 20.-50. IV wieku.

Pierwsze synody Kościoła wschodniego zwoływane po 325 roku były odzwierciedleniem sporów teologicznych i administracyjnych, związanych w dużej mierze z przyjęciem nauczania Nicei. Synod w Antiochii (około 328 roku) był zwołany przeciwko Eustatiosowi z Antiochii i Asklepasowi, z których pierwszy był oskarżony

4 Por. S. Bralewski, Cesarz Konstantyn I Wielki wobec kontrowersji ariańskiej, Poznań 2009, s. 28 (Labarum, VIII).

5 Por. H. Pietras, Sobór Nicejski (325)..., dz. cyt., s. 213.

6 Eusebii Caesariensis epistola ad suae parociae homines 8, [w:] Patrologia Graeca, ed. J. P. Migne, Paris 1857-1866, t. 20, kol. 1539-1540 [dalej publikacje z tej serii cytowane jako: PG i numer tomu]; tłum. polskie (A. Baron): List Euzebiusza z Cezarei do swego Kościoła, 8, [w:] Dokumenty Soborów Powszechnych, tekst grecki, łaciński, polski, red. A. Baron, H. Pietras, t. 1, 325-787, Kraków 2001, s. 56-57 (Źródła Myśli Teologicznej, 24 [dalej publikacje z tej serii cytowane jako: ŹMT i numer tomu]).

7 Atanazy z Aleksandrii, De decretis Nicaenae synodi, [w:] Athanasius, PG 25b, kol. 416-476; tłum. polskie: O dekretach Soboru Nicejskiego, tłum. P. M. Szewczyk, Kraków 2011, s. 1-33 (ŹMT 60).

8 P. M. Szewczyk (Wprowadzenie, s. XXIII, [w:] ŹMT 60) postuluje lata 345-355 jako datację ogólną napisania przez Atanazego listu o postanowieniach Synodu Nicejskiego. Za wczesną datacją tego listu (345) optuje E. Cattaneo, natomiast większość badaczy opowiada się jednak za datacją późniejszą: latami 350-351 (G. H. Optiz); 351-355 (A. Roberson; M. Simonetti); 357-359 (X. Morales); por. P. M. Szewczyk, Wprowadzenie, dz. cyt., s. XXIII. 
o monarchianizm i niemoralność. Kolejny Synod w Antiochii (około 331-334) miał być zwołany przeciwko wierze nicejskiej, lecz jego istnienie wydaje się dziś mało wiarygodne. Synod w Tyrze (335), przeciwko Atanazemu, nie poruszył kwestii credo. Synod w Jerozolimie (335) rehabilitował Ariusza, którego wyznanie wiary uznano za ortodoksyjne. Synod w Aleksandrii (338-339) odbył się w obronie Atanazego, lecz również nie odniósł się do credo z 325 roku. Synod w Konstantynopolu (338-339) złożył z urzędu Pawła z Konstantynopola, lecz znowu zabrakło tu odniesień do symbolu nicejskiego. Synod w Gangra (około 340 roku) wystąpił przeciwko Eustatiosowi z Sebasty i przesadnej ascezie, lecz w jego aktach także brak odniesień do credo nicejskiego. Synod w Antiochii (341), pragnąc ułożyć wyznanie wiary lepsze od nicejskiego, podał natomiast aż trzy wyznania wiary, z których jedynie drugie było oficjalnym symbolem tego synodu? Był to swoisty początek układania kolejnych, w zamyśle lepszych niż nicejskie, symboli wiary.

Giuseppe Luigi Dossetti w wydaniu krytycznym tekstu credo nicejskiego, podając świadków przekazu tekstu, opisuje kolekcje kanoniczne, zawierające tekst soborowego wyznania z 325 roku:

- Corpus Canonum, antyczną kolekcje kanoniczną grecką (powstałą według Eduarda Schwartza i Alphonse'a van Hovego w dwóch fazach: latach 361-376 i 381-451);

- świadków greckich tekstu wyznania odnoszących się do Corpus Canonum (tj. Mandatum orientalium in gestis Ephesini concilii, tekst z 431 roku);

- Gelasius Cyzicenus in Historia Ecclesiastica 2, 27; tekst powstały po 475 roku);

- Corpus Canonum w języku syryjskim (przekłady z tekstów greckich na syryjski, powstałe pomiędzy 501 rokiem a IX wiekiem);

- Corpus Canonum w języku koptyjskim (przekłady z greckiego, powstałe pomiędzy 400 a 550 rokiem);

- łacińskie kolekcje kanoniczne (przekłady z greckiego, powstałe w latach: 402, 419, 422);

- listę ojców soborowych z Nicei (w języku greckim: Sokrates Scholastyk, Historia Ecclesiastica 1,13,11; w językach: syryjskim,

9 Por. Dokumenty synodów od 50 do 381 roku, red. A. Baron, H. Pietras, Kraków 2006, s. 90-142 (ŹMT 37). 
koptyjskim i armeńskim: przekłady z Corpus Canonum; w języku łacińskim, listy tworzone od 774 roku do XI wieku)

- oraz apendyks antiocheński (syryjskie wyjaśnienie Corpus Canonum $)^{10}$.

Z zestawienia G. L. Dossettiego wynika zatem, że wszystkie antyczne kolekcje kanoniczne zawierające tekst wyznania soborowego z Nicei I to zbiory prawne powstałe od 360 roku do XI wieku. Są zatem późniejszymi świadkami tekstu credo nicejskiego.

Kwestię słabej recepcji credo nicejskiego na Wschodzie w IV i V wieku wnikliwie omówił ostatnio Henryk Pietras, który wykazał, że „nie ma żadnego śladu, by ktokolwiek, kiedykolwiek i do czegokolwiek go używał w Kościele"11. Po soborze w Nicei żaden z Kościołów lokalnych do owego credo nicejskiego się nie przyznawał. Kościoły partykularne posługiwały się własnymi wersjami credo chrzcielnego. Co więcej, można się doliczyć 18 synodów, które układały nowe wyznania wiary, ale nie odwoływały się do „Wyznania wiary $318 \mathrm{Oj}$ ców"12. Od około 350 roku Atanazy zaczął promować credo nicejskie, gdyż prawdopodobnie nabrał przekonania, że układanie nowych wyznań wiary prowadzi donikąd. Owa promocja okazała się skuteczna, gdyż Synod Konstantynopolitański z 381 roku zakazał zmian w credo nicejskim ${ }^{13}$, co powtórzył Sobór Efeski z 431 roku ${ }^{14}$.

10 G. L. Dossetti, Il simbolo di Nicea e di Costantinopolo: edizione critica, Roma-Freiburg-Basel 1967, s. 113-167.

$11 \quad$ H. Pietras, Sobór Nicejski (325)..., dz. cyt., s. 180.

12 Por. H. Pietras, Spór o wyznanie wiary w IV wieku, „Teologia Patrystyczna” $2007 \mathrm{nr} 4$, s. 35-50; H. Pietras, Sobór Nicejski (325)..., dz. cyt., s. 185.

13 Sobór Konstantynopolitański I, kanon I: „Wyznania wiar świętych Ojców zebranych w Nicei w Bitynii nie wolno zmieniać, lecz należy je zachować z cała jego mocą". ŹMT 24, s. 71 .

14 Sobór Efeski, Orzeczenie o nicejskim wyznaniu wiary: „Taką wiarę ustalił sobór w Nicei: «Wierzymy... (tekst wyznania wiary Soboru Nicejskiego I)». Byłoby rzeczą słuszną, aby wszyscy zgadzali się z tą świętą wiarą. Jest ona pobożna i pożyteczna dla całego świata. Skoro niektórzy tylko udają, że wyznają taką wiarę i zgadzają się z nią tylko pozornie, błędnie tłumaczą jej prawdziwy sens, interpretują ją zgodnie z własnym sposobem myślenia i pouczają prawdę jako synowie błędu oraz dzieci potępienia, uznano za konieczne sięgnąć do świadectw świętych i prawowiernych Ojców, aby mogły ukazać, w jaki sposób oni pojmowali wiarę i z odwagą ją głosili, tak ażeby było oczywiste, że wszyscy ci, których wiara jest prawdziwa i nienaganna, w ten właśnie sposób ja rozumieją, wyjaśniają i głoszą (tu następowała lektura fragmentów z Pism Ojców, wypowiedzi uczestników soboru oraz relacji dotyczącej prezbitera Charyzjusza...). Po przeczytaniu tych dokumentów sobór zarządził, że: [kanon VII] 
Pomimo wymienionych apeli soborowych credo z Nicei I nadal nie było formalnie używane w Kościele, podobnie jak credo Synodu w Konstantynopolu z 381 roku. Co więcej, ten sam Synod w kanonie III zaczął upowszechniać tezę o przewodniej roli Kościoła Konstantynopola na Wschodzie, co oczywiście nie znalazło zrozumienia ani w Rzymie, ani w Aleksandrii. Kanon XXVIII Soboru Chalcedońskiego z 451 roku powtórzył uzasadnianą wyłącznie politycznie doktrynę o precedencji biskupstwa konstantynopolitańskiego na Wschodzie. Jednak Konstantynopola jako miasta soborowego czy apostolskiego nadal nie wymieniano w dokumentach kościelnych nawet pod koniec V wieku. Brakuje wzmianek o soborowości Konstantynopola w Liście papieża Feliksa do duchowieństwa Konstantynopola z 484 roku (jako miasta soborów zostały wymienione jedynie: Nicea, Efez i Chalcedon). Brak również wzmianek o apostolskości Konstantynopola w oryginale Dekretu Gelazego z 495 roku (jako apostolskie zostały wymienione jedynie Rzym, Aleksandria i Antiochia) ${ }^{15}$.

Wobec powyższych danych $\mathrm{H}$. Pietras wyprowadza opinię celowego fałszerstwa i wymuszenia na Rzymie uznania dla Konstantynopola. Jako że do akceptacji kościelnej stołeczności Konstantynopola brakowało argumentacji teologicznej (temu biskupstwu brakowało zarówno sukcesji apostolskiej, jak i miejsca w tradycji soborowej), wymyślono określenie ważności Konstantynopola ze względu na jego miejsce w tradycji soborowej ${ }^{16}$.

Nikomu nie wolno głosić, spisywać ani formułować innej wiary niż ta, która została ustalona przez świętych Ojców zgromadzonych w Nicei wraz z Duchem Świętym. Ci, którzy ośmielają się inną wiarę formułować, rozpowszechniać lub głosić pragnącym nawrócić się z pogaństwa, judaizmu czy jakiejkolwiek herezji i poznać prawdziwą wiarę - to jeśli są biskupami albo duchownymi mają być pozbawieni urzędu: biskupi episkopatu, duchowni przynależności do kleru; jeśli zaś są to osoby świeckie, mają być wyłączone ze wspólnoty Kościoła”. ŹMT 24, s. 167, 169.

15 Por. H. Pietras, Sobór Nicejski (325)..., dz. cyt., s. 187-188.

16 H. Pietras stwierdza: „Pokazanie wyznania wiary jako ułożonego w Konstantynopolu przez 150 ojców, z całym respektem dla nicejskiego, ale z - jakoby - koniecznym dopiskiem o Duchu Świętym przeciwko macedonianom, miało służyć wprowadzeniu Konstantynopola do ekskluzywnego klubu najważniejszych miast chrześcijaństwa, już nie tylko ze względu na stołeczność, ale i soborowość. Trzeba przyznać, że manewr się powiódł i w końcu w 519 roku w raporcie legatów papieża Hormizdasa z Konstantynopola pojawia się wiadomość o czterech soborach i jak podaje Thiel w przypisie, od tego czasu w Rzymie mówi się właśnie o czterech, a nie o trzech, jak 
Znaczącą okolicznością praktycznego odrzucenia credo nicejskiego na rzecz konstantynopolitańskiego była kwestia monofizytyzmu, walki o władzę pomiędzy cesarzem Zenonem Izauryjczykiem (rządził w latach 474-491) a uzurpatorem Bazyliskusem (475-476) oraz eklezjalnych sporów o uznanie Soboru Chalcedońskiego i przewodniej roli Konstantynopola w Kościele na Wschodzie w latach 70. V wieku (czego nie chciały uznać patriarchaty Antiochii i Aleksandrii). Kiedy uzurpator Bazyliskus odwołał z wygnania antychalcedonianina, patriarchę Antiochii Piotra Folusznika (biskupa Antiochii w latach 471488), ten wprowadził zwyczaj odmawiania w czasie mszy wyznania wiary; prawdopodobnie było to credo nicejskie. Prawdopodobnie byłoby to jedyne liturgiczne użycie nicejskiego wyznania wiary w starożytności - paradoksalnie przez monofizytów w Antiochii ${ }^{17}$. Natomiast od VI wieku zaczęto promować credo konstantynopolitańskie, uznawane według kościelno-politycznej argumentacji przyjętej w Chalcedonie jako przedłużenie credo nicejskiego ${ }^{18}$.

\section{Recepcja credo nicejskiego w nauczaniu synodalnym Kościoła zachodniego}

Dla zrozumienia recepcji credo nicejskiego w Kościele zachodnim fundamentalną kwestią jest odbiór tego wyznania wiary w nauczaniu synodalnym w IV wieku. Na Zachodzie pierwszym łacińskim świadkiem pełnego tekstu credo z Nicei I był Hilary z Poitiers, czego dowodem jest traktat z 359 roku O synodach, albo o wierze Wscho$d u^{19}$. Było to jednak pojedyncze powołanie się na treści soborowego symbolu przez pojedynczego biskupa. W Kościele starożytnym

dotąd". Por. H. Pietras, Sobór Nicejski (325)..., dz. cyt., s. 188, przypis 40 (A. Thiel, Epistolae Romanorum Pontificium genuinae I, Epis. 76, 4, s. 873).

17 Por. H. Pietras, Sobór Nicejski (325)..., dz. cyt., s. 188-189; P. Th. Camelot, Creeds, [w:] Sacramentum mundi. An encyclopedia of theology, ed. K. Rahner, C. Ernst, K. Smyth, t. 2, London $1973^{5}$, s. 39.

18 Por. M. Righetti, Manuale di storia liturgica, vol. III, L'Eucaresita. Sacrificio e sacramento, Milano 1998, s. 294-296; H. Pietras, Sobór Nicejski (325)..., dz. cyt., s. $189-190$.

19 Hilary z Poitiers, De synodis seu de fide Orientalium 84 (Patrologia Latina, ed. J. P. Migne, Paris 1844-1855, t. 10, kol. 536 [dalej publikacje z tej serii cytowane jako: PL i numer tomu]). 
panowało natomiast przekonanie, że nie tyle każdy biskup z osobna, ale wszyscy biskupi są następcami całego kolegium apostolskiego. Opinie kolegium biskupiego spotykającego się na synodach były zatem wiążące dla danych kościołów lokalnych, gdyż synody były wyrazem kolegialności, apostolskości i jedności eklezjalnej całego Kościoła lokalnego. Dlatego chcę teraz przeprowadzić analizę treści akt synodalnych Kościoła zachodniego z lat 325-399 pod kątem recepcji credo nicejskiego. Pragnę opisać sposób, w jaki Synody zachodnie odwoływały się do tekstu credo z 325 roku. W pracy będę używał bilingwicznej edycji tekstów synodalnych wydanych w serii Źródła Myśli Teologicznej w tomach 37 i 52.

Synod w Rzymie (325? $)^{20}$, na którym miało nastąpić zatwierdzenie uchwał Soboru Nicejskiego I wydaje się dziś badaczom mało prawdopodobny ${ }^{21}$.

Synod w Kartaginie (około 335 roku) ${ }^{22}$ był synodem donacjańskim, na którym ustalono, że katolicy przechodzący do donatystów nie muszą być ponownie chrzczeni ${ }^{23}$. Brak wzmianek o credo nicejskim.

Synod w Rzymie (lata 340-341), w obronie Atanazego z Aleksandrii i Marcelego z Ancyry, do którego dokumentów dołączono list Juliusza I, papieża ${ }^{24}$. Jest $\mathrm{w}$ nim mowa o potępieniu arian przez uchwały Soboru Nicejskiego I (List Juliusza I 23, 1-425), o wyznaniu wiary przez Marcelego z Ancyry, który zwiódł papieża, przedstawiając mu Skład apostolski jako własne wyznanie wiary (List Juliusza I, 32, 1-2 $\left.{ }^{26}\right)$. Ciekawe, że Vitus i Vincentius, legaci papiescy

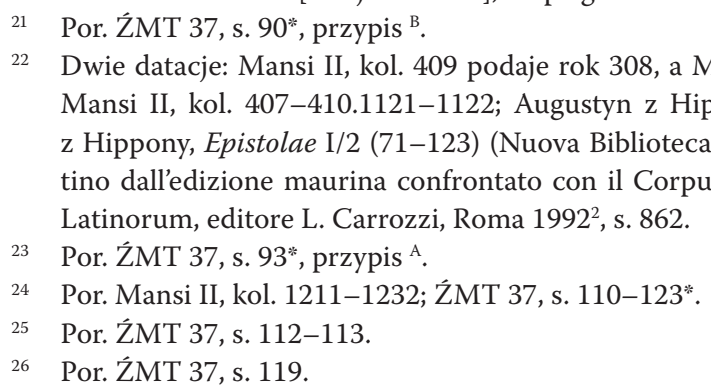

21 Por. ŹMT 37, s. 90*, przypis ${ }^{\text {B }}$. Latinorum, editore L. Carrozzi, Roma $1992^{2}$, s. 862.

23 Por. ŹMT 37, s. 93*, przypis ${ }^{\text {A. }}$.

24 Por. Mansi II, kol. 1211-1232; ŹMT 37, s. 110-123*.

25 Por. ŹMT 37, s. 112-113.

26 Por. ŹMT 37, s. 119.

D. Mansi, Sacrorum conciliorum nova et amplissima colectio, vol. II, Ab anno 305 ad annum 346 [dalej: Mansi II], Leipzig-Paris 1901, kol. 1081-1083.

22 Dwie datacje: Mansi II, kol. 409 podaje rok 308, a Mansi II, kol. 1121 rok 333; Por. Mansi II, kol. 407-410.1121-1122; Augustyn z Hippony, Epistula, [w:] Augustyn z Hippony, Epistolae I/2 (71-123) (Nuova Biblioteca Agostiniana, XXI/2). Testo latino dall'edizione maurina confrontato con il Corpus Scriptorum Ecclesiasticorum 
obecni na soborze, potwierdzili prawowierność Marcelego ${ }^{27}$. Nie ma natomiast jakiegokolwiek bezpośredniego odniesienia do tekstu samego credo nicejskiego.

Synod w Sardyce (Sofii), około 343 roku $^{28}$, na którym, po opuszczeniu go przez 76 biskupów wschodnich, było obecnych 97 biskupów zachodnich $^{29}$. Ojcowie synodalni ułożyli formułę wiary ${ }^{30}$, mającą raczej charakter wyjaśnienia niż symbolu ${ }^{31}$. W formule wiary z Sardyki znowu brak powołania się na tekst credo z Nicei.

Synod w Mediolanie (około 345-346 roku) ${ }^{32}$ w sprawie symbolu wiary z Antiochii (344-345), przywiezionego przez tamtejszą delegację. Biskupi wschodni i zachodni nie doszli do porozumienia względem potępienia Ariusza ${ }^{33}$. Brak wzmianek o credo z Nicei z 325 roku.

Synod w Kolonii (12 maja 346 roku $)^{34}$, któremu przewodniczył Maksymin, biskup Turynu, celem złożenia z urzędu biskupa Kolonii Eufratasa, jakoby przeczącemu bóstwu Chrystusa, co badaczom trudno przyjąć za oczywiste, gdyż biskup Kolonii jeszcze w 343 roku uchodził za ortodoksyjnego ${ }^{35}$. W tekście dokumentu brak jakichkolwiek powołań na credo nicejskie.

Synod w Mediolanie (około 347-348 roku) ${ }^{36}$, potępienie Fotyna z Sirmium i przyjęcie listu Ursacjusza z Singidunum (Belgrad)

27 Por. Mansi II, kol. 692D: „Scilicet Vitus et Vincentius, legates papae”; List Juliusza I 32, 2: „A nasi prezbiterzy, którzy ongiś brali udział w Soborze Nicejskim, potwierdzili jego prawowierność".

28 Por. J. D. Mansi, Sacrorum conciliorum nova et amplissima colectio, vol. III, Ab anno 347 ad annum 409 [dalej: Mansi III], Florentiae 1759, kol. 1-74; ŹMT 37, s. $143-183^{*}$.

29 Por. J. Gliściński, Wspótistotny Ojcu, Łódź 1992, s. 59-62.

30 Por. ŹMT 37, s. 143-145.

31 Por. ŹMT 37, s. 143*, przypis ${ }^{\text {A }}$.

32 Por. Mansi II, kol. 1369-1372; ŹMT 37, s. 188-188*.

33 Por. ŹMT 37, s. $188^{*}$, przypis ${ }^{\mathrm{D}}$.

34 Por. Mansi II, kol. 1371-1374; ŹMT 37, s. 189-191*.

35 Por. ŹMT 37, s. 189, przypis ${ }^{\text {A }}$.

36 Por. Mansi III, kol. 159-162; ŹMT 37, s. 193-193*. 
i Walensa z Mursy, w którym obaj biskupi zapewniali, że są gotowi potępić Ariusza. Brak wzmianek o credo z Nicei I.

Synod w Kartaginie (około 348 roku) ${ }^{37}$ przeciw donatystom. Brak odniesień do credo nicejskiego.

Synod w Hadrumentum w prowincji Byzacena (około 348 roku) ${ }^{38}$ w sprawie lichwy. Brak powołania się na tekst credo z Nicei.

Dwa synody numidyjskie z 348 roku: donatystyczny (w obliczu prześladowania donatystów ze strony cesarstwa po zamordowaniu przez nich biskupa Marculusa) ${ }^{39}$ oraz katolicki (odmawiający tytułu męczennika donatystom, którzy mieli sami wydawać się na śmierć $\mathrm{z}$ nieumiarkowanego pragnienia męczeństwa $)^{40}$. Brak jakichkolwiek odniesień do credo soborowego.

Synod w Rzymie (349) ${ }^{41}$, za papieża Juliusza I, potępienie Fotyna. Brak powołań na credo nicejskie.

Synod w Sirmium (Hrvatska Mitrovica, Bośnia) z 351 roku ${ }^{42}$, pierwsze wyznanie wiary z Sirmium (tzw. Pierwsza formuła $z$ Sirmium). W tej ariańskiej formule, która stanowi dosłowne powtórzenie IV formuły antiocheńskiej (z 342 roku), poszerzonej o 26 anatematyzmów ${ }^{43}$, również brak odwołań do credo z Nicei z 325 roku.

Synod w Rzymie (lata 352-353) ${ }^{44}$ za papieża Liberiusza, w obronie Atanazego. Brak odniesień do credo nicejskiego.

Synod w Arles (353) ${ }^{45}$, zwołany przez cesarza Konstancjusza II celem potępienia Atanazego. Brak wzmianek o credo z Nicei I.

\footnotetext{
Por. Mansi III, kol. 143-158; ŹMT 37, s. 193-199*.

Por. Mansi III, kol. 145; ŹMT 37, s. 200-200*.

Por. Mansi III, kol. 143-144; ŹMT 37, s. 200-200*.

Por. Mansi III, kol. 152; ŹMT 37, s. 200-200*.

Por. Mansi III, kol. 163-166; ŹMT 37, s. 200-200*.

Por. Mansi III, kol. 257-260; ŹMT 37, s. 200-205*.

Por. J. Gliściński, Wspótistotny Ojcu, dz. cyt., s. 72-73.

Por. Mansi III, kol. 229; ŹMT 37, s. 206-206*.

Por. Mansi III, kol. 231; ŹMT 37, s. 206-206*.
} 
Synod w Mediolanie (355) ${ }^{46}$, zwołany przez cesarza Konstancjusza II w celu potępienia Atanazego. Brak odniesień do credo nicejskiego.

Synod w Galii (355) ${ }^{47}$, odrzucający postanowienia Synodu Mediolańskiego z 355 roku. Brak wzmianek o credo soborowym.

Synod w Béziers (356) ${ }^{48}$, zwołany przez ariańskiego biskupa Arles, Saturninusa, celem zesłania Hilarego z Poitiers. Brak odwołań do credo nicejskiego.

Synod w Sirmium $(357)^{49}$, zwołany przez anomejczyków, odrzucający sformułowanie „współistotny” z symbolu z Nicei (Druga formuta $z$ Sirmium 3), podkreślający, że Bóg Ojciec jest większy od Syna (Druga formuta $z$ Sirmium 4). Na synodzie tym nastąpiło przyjęcie Drugiej formuty wiary $z$ Sirmium ${ }^{50}$.

Synod w Galii (357-358) ${ }^{51}$, potępiający tzw. Druga formułę z Sirmium. Brak odwołań do credo z Nicei.

Synod w Sirmium $(358)^{52}$, synod ariański, zwołany przez Bazylego z Ancyry, odrzucający Druga formutę z Sirmium, a powołujący się na druga formułę wiary z Antiochii z 341 roku, anatematyzmy z Sirmium z 351 roku i z Ancyry z 358 roku. Zaakceptowane dokumenty łącznie nazywa się Trzecia formuła $z$ Sirmium. Brak formalnych odniesień do credo nicejskiego.

Synod w Sirmium (maj 359) s3 $^{3}$ synod ariański, który uchwalił tzw. Czwarta formutę $z$ Sirmium, potępiającą użycie terminu ovøı a odniesieniu do Ojca i Syna jako terminu niebiblijnego ${ }^{54}$, a wprowadzającą

Por. Mansi III, kol. 233-237; ŹMT 37, s. 207-207*.

Por. Mansi III, kol. 251-252; ŹMT 37, s. 207-207*.

8 Por. Mansi III, kol. 251-254; ŹMT 37, s. 208-208*.

49 Por. Mansi III, kol. 261-264; ŹMT 37, s. 208-209*.

50 Por. J. Gliściński, Wspótistotny Ojcu, dz. cyt., s. 84-85.

Por. Mansi III, kol. 291-292; ŹMT 37, s. 209-209*.

Por. Mansi III, kol. 289n; ŹMT 37, s. 225-225*.

53 Por. Mansi III, kol. 253-266; ŹMT 37, s. 225-226*.

54 Czwarta formuła z Syrmium 8, 7, [w:] ŹMT 37, s. 226”: „Nazwę ousia wprowadzili Ojcowie gwoli uproszczenia. Niezrozumiana przez pospólstwo przynosi zgorszenie, 
termin „Syn podobny jest pod każdym względem do Ojca” ${ }^{55}$. Brak bezpośredniego odwołania się do tekstu credo nicejskiego.

Synod w Rimini (maj-październik 359 roku) ${ }^{56}$, synod dla Zachodu (jego wschodnim odpowiednikiem był synod w Seleucji w 359 roku) zwołany przez cesarza Konstancjusza II. Około 400 biskupów wbrew cesarzowi nie przyjęło Czwartej formuly $z$ Sirmium i opowiedziało się za nicejską formułą wiary, lecz bez cytowania pełnego tekstu wyznania ${ }^{57}$. Jednak pod naciskiem cesarza biskupi ostatecznie przyjęli formułę z Nike z 359 roku $^{58}$.

Synod w Paryżu (lata 360-361) (59 $^{5}$ synod pod przewodnictwem Hilarego z Poitiers, odrzucając ariańskie tezy z Rimini odwołał się bezpośrednio do credo nicejskiego i przyjął „wyrażenie «współistotny» na określenie prawdziwego i rzeczywistego zrodzenia jednorodzonego Boga z Boga Ojca. [...]. Dlatego wyznajemy, że jest jedną «ousią» lub «substancją» z Bogiem Ojcem, aby nie uważano Go za stworzenie, adopcję ani samą nazwę"60.

gdyż nawet i tekst Pisma jej nie zawiera. Postanowiliśmy ją przeto usunąć i absolutnie nie dopuścić na przyszłość do żadnej wzmianki o ousii w odniesieniu do Boga, ponieważ Pismo Święte nigdzie nie wspomina o ousii Ojca i Syna”.

55 Czwarta formuta z Syrmium 8, 7, dz. cyt.

56 Por. Hilarius Pictaviensis, Tractatus mysteriorum, Fragmenta, Ad Constantium Imperatorem, Hymni; Pseudo-Hilarius, Epistula ad Abram filiam, Hymni, ed. A. Feder, Wien-Leipzig 1916, kol. 95-96 (Corpus Scriptorum Ecclesiasticorum Latinorum [dalej: CSEL], 65; PL 10, kol. 697); ŹMT 37, 226-226*.

57 Synod w Rimini (359), Definicja wiary homouzjan 3, [w:] ŹMT 37, s. 226*-227*: „Tak wierzymy, że można się podobać wszystkim katolikom, iż nie wolno nam odchodzić od przyjętego wyznania wiary, [...] i że nie odstąpimy od wiary [...] tak jak ciągle trwa ustanowiona, przez tradycję ojców według sukcesji apostołów aż do Soboru Nicejskiego zwołanego przeciw herezji, która w owym czasie powstała"; Synod w Rimini (359), List synodu z Rimini do cesarza Konstancjusza 1: „Uznaliśmy za rzecz niegodną zniekształcanie w czymkolwiek ustaleń świętych ojców i tych, którzy zasiedli na soborze nicejskim razem z przesławnej pamięci Konstantynem, ojcem waszej miłości". ŹMT 37, s. 229\%.

58 List synodalny arian do cesarza Konstancjusza o odrzuceniu terminu «substancja», [w:] ŹMT 37, s. 231-232*.

59 Por. Mansi III, kol. 357; ŹMT 37, s. 246-249*.

60 Synod w Paryżu (360/361), Wiara katolicka 2, [w:] ŹMT 37, s. 247*; por. Wiara katolicka 3, [w:] ŹMT 37, s. 248*: „Tej wiary zawsze się trzymamy i będziemy się trzymać brzydząc się tymi, którzy mówią: «Nie było go zanim się narodził». 
Synod w Thenae w Byzacena (około 362) ${ }^{61}$, synod donatystyczny. Brak wzmianek o credo nicejskim.

Synod w Rzymie (lata 365-366) ${ }^{62}$, za papieża Liberiusza, rehabilitujący Eustatiosa z Sebasty. Dokumentem, jaki pozostał po tym synodzie, jest List Liberiusza do biskupów macedońskich. $\mathrm{Na}$ tym synodzie rzymskim bezpośrednio odwołano się do credo nicejskiego i załączono je do listu papieskiego, samo credo soborowe określono jako: „katolickie i apostolskie”63, „zatwierdzone przez ortodoksyjnych biskupów i zawierające doskonałą prawdę"64, wyrażające wiarę "zawartą w pojęciu hipostazy i wyrażoną w terminie współistotnego"65, „Credo, ogłoszone w Nicei jako obowiązujące" ${ }^{66}$.

Synod na Sycylii (366) ${ }^{67}$, potwierdzający credo nicejskie i rehabilitujący Eustatiosa z Sebasty.

Synod w Singidunum (obecnie Belgrad; 366$)^{68}$, synod ariański, odrzucający określenie „podobieństwo Ojca i Syna co do istoty”.

Synod w Rzymie (368) ${ }^{69}$, za papieża Damazego, potępiający Ursacjusza i Walensa. Brak bezpośrednich odniesień do credo nicejskiego.

61 Por. Mansi III, kol. 373-374; ŹMT 37, s. 256-256\%.

62 Por. Mansi III, kol. 377-380; ŹMT 37, s. 261-263\%.

63 List Liberiusza do biskupów macedońskich 3, [w:] ŹMT 37, s. 261*-262*: „Za katolicką i apostolską uznajemy wiarę, która w czystej i nienaruszonej postaci przetrwała aż do soboru w Nicei. I tę właśnie wiarę wyznali sami posłowie i pełni radości usuwając wszelki ślad i zarzewie niedorzecznego podejrzenia przedstawili ją nie tylko w mowie, ale także na piśmie. Kopię tego dokumentu uznaliśmy za potrzebne załączyć bezwzględnie do niniejszego pisma, żeby nie zostawić heretykom jakiegoś pretekstu do ponownych knowań i zasadzek".

64. List Liberiusza do biskupów macedońskich 4, [w:] ŹMT 37, s. 262*: „...wiarę zatwierdzoną w Nicei przez trzystu osiemnastu ortodoksyjnych biskupów, która zawiera doskonała prawdę i zmusza do milczenia i do ucieczki całe zastępy heretyków".

65 List Liberiusza do biskupów macedońskich 5, [w:] ŹMT 37, s. 262*.

66 List Liberiusza do biskupów macedońskich 6, [w:] ŹMT 37, s. 262*.

67 Por. ŹMT 37, s. 263-263\%.

68 Por. Mansi III, kol. 399-402; ŹMT 37, s. 263-264\%.

69 Por. Mansi III, kol. 447-448; ŹMT 37, s. 264-264\%. 
Synod w Rzymie (ok. 370) ${ }^{70}$, za Damazego, potępienie Auksencjusza z Mediolanu za arianizm. Bezpośrednie powołanie się na credo z Nicei jako na odtrutkę na arianizm i zbawienne wyznanie wiary ${ }^{71}$, gdyż zawiera ono wiarę opartą na autorytecie apostołów ${ }^{72}$.

Synod w Valence d'Agen (12 lipca 374 roku $)^{73}$ o święceniach, pokucie i powtórnym chrzcie. Brak wzmianek o credo z Nicei.

Synod w Rzymie (374) $)^{74}$, za Damazego, pośrednie powołanie się na credo nicejskie przy potępieniu Eustatiosa z Sebasty za negowanie współistotności Ojca i Syna oraz za zaprzeczanie bóstwu Ducha Świętego, oraz potępienie Apolinarego z Laodycei za negowanie pełnego człowieczeństwa Chrystusa.

Synod w Rzymie (lata 376-377) ${ }^{75}$, przeciwko Apolinaremu z Laodycei, Eustatiosowi z Sebasty, Melecjuszowi z Antiochii i Euzebiuszowi z Samosaty. Pośrednie powołanie się na credo nicejskie przy anatematyzmach Tomus Damasi.

Synod w Ilirii (378) ${ }^{76}$ o wierze nicejskiej. Podawana jest dziś w wątpliwość autentyczność tego soboru.

Synod w Rzymie (378) ${ }^{77}$ dla odparcia oszczerstw żydowskiego podżegacza Izaaka i omówienia jurysdykcji kościelnej. Brak odwołań do credo z Nicei I.

70 Por. Mansi III, kol. 455-462; ŹMT 37, s. 275-277*.

${ }^{71}$ List „Confidimus” do biskupów wschodnich 3, [w:] ŹMT 37, s. 276”: „najświętsi biskupi, na Soborze w Nicei ten mur zbudowali dla obrony przed diabelskim orężem i taką odtrutkę zastosowali na kielich zabójczego jadu, że trzeba wierzyć w Ojca, Syna i Ducha Świętego, jednego Bóstwa, jednej postaci, jednej substancji, orzekając przeciw tym, którzy myśleli odmiennie niż nasza wspólnota. To zbawienne wyznanie wiary później niektórzy na innych synodach próbowali obalić i pogwałcić”.

72 List „Confidimus” do biskupów wschodnich 4, [w:] ŹMT 37, s. 276“: „stale trzeba trwać jedynie przy tej wierze, która została oparta w Nicei na autorytecie Apostołów".

73 Por. Mansi III, kol. 491-496; ŹMT 37, s. 280-282*.

74 Por. Mansi III, kol. 477-482; ŹMT 37, s. 282-282".

75 Por. Augustinus, De Trinitate, ed. W. J. Mountain, F. Glorie, Turnhout 1968, s. $564-$ 565 (Corpus Christianorum. Series Latina [dalej: CCL], 50A); ŹMT 37, s. 285-288*.

76 Por. Mansi III, kol. 386; ŹMT 37, s. 288-288*.

77 Por. Mansi III, kol. 501; ŹMT 37, s. 282-292*. 
Synod w Saragossie (4 października 380 roku) ${ }^{78}$ przeciwko pryscylianom. Brak wzmianek o credo nicejskim.

Synod w Rzymie (380 ${ }^{79}$ w sprawie Maksyma Cynika. Brak odniesień do credo nicejskiego.

Synod w Mediolanie (380) ${ }^{80}$, za Ambrożego, w sprawie dziewicy Indicji z Werony o przekroczenie ślubu czystości. Uwolniona od zarzutu. Brak wzmianek o credo nicejskim.

Synod w Akwilei (3 września 381 roku) ${ }^{81}$, potępienie Palladiusza ${ }^{82}$ i Sekundiana ${ }^{83}$ oskarżonych o arianizm, pośrednio potwierdzenie credo z Nicei, którego nie wyznawali sądzeni arianie.

Synod w Mediolanie (około 381? ${ }^{84}$, prawdopodobnie synod tożsamy z Synodem w Akwilei z 381 roku.

Synod w Rzymie (382) ${ }^{85}$, podanie kanonu Pisma Świętego, odrzucenie tezy o prymacie Kościoła w Konstantynopolu. Brak odniesień do credo z Nicei I.

Synod w Bordeaux (384-385) ${ }^{86}$, przeciwko Pryscylianowi i Instancjuszowi. Brak odniesień do credo nicejskiego.

78 Por. Mansi III, kol. 633; ŹMT 37, s. 292-294\%.

79 Por. Mansi III, kol. 519-520; ŹMT 37, 294-294\%.

80 Por. Mansi III, kol. 317-318; ŹMT 37, s. 295-295\%.

81 Por. Mansi III, kol. 601-615; Dokumenty synodów od 381 do 431 roku, red. A. Baron, H. Pietras, Kraków 2010, s. 1-24\%(ŹMT 52).

82 Akta synodu akwilejskiego 53, [w:] ŹMT 52, s. 18*: Biskup Ambroży powiedział: „[...] potępiamy Palladiusza, ponieważ nie chciał potępić tez bezbożnego Ariusza i ponieważ sam zaprzeczył, że Syn Boży jest wieczny oraz pozostałym prawdom, co zachowano w aktach. Niech więc będzie wyklęty. Wszyscy biskupi powiedzieli: Wszyscy go potępiamy. Niech będzie wyklęty".

83 Jak odnotowują wydawcy (ŹMT 52, przypis ${ }^{\text {A }}$, s. 24*; por. Ambroży z Mediolanu, Epistula 1(9), 2 (9), ed. O. Faller, M. Zelzer, Wien 1968-1996, s. 315-325 (CSEL 82/1)), protokół przesłuchania urywa się, jednak samo przesłuchanie Sekundiana zakończyło się potępieniem, tak jak przesłuchanie Palladiusza.

84 Por. Mansi III, kol. 631-632; Ambroży z Mediolanu, Epistulae 13, 14, [w:] Ambrosius Mediolanensis (PL 16, kol. 950.953); ŹMT 52, s. 24-24\%.

85 Por. Mansi III, kol. 640; ŹMT 52, s. 29-33*.

86 Por. J. Gaudemet, Conciles gaulois du IVe siécle, Paris 1977 s. 113-116 (Sources Chrétiennes, 241); ŹMT 52, s. 34-35*. 
Synod w Rzymie (385) ${ }^{87}$ w sprawach dyscyplinarnych. Brak powołań na credo nicejskie.

Synod w Trewirze (385-386 $)^{88}$, potępienie Itacjusza za surowość w zwalczaniu Pryscylian. Brak odniesień do credo nicejskiego.

Synod w Rzymie (6 stycznia 386 roku $)^{89}$ w sprawach dyscyplinarnych. Brak wzmianek dotyczących credo z Nicei.

Synod w Kartaginie (389) ${ }^{90}$, synod prowincjalny, przygotowujący synod plenarny Afryki na rok 390. Brak wzmianek o credo nicejskim.

Synod w Kartaginie (16 czerwca 390 roku) ${ }^{91}$, zbiór kanonów doktrynalnych i dyscyplinarnych. Ogólne odwołanie się do treści credo nicejskiego ${ }^{92}$.

Synod w Rzymie (około 390) (33 $^{3}$ przeciw Jowinianowi negującemu dziewictwo Najświętszej Panny Maryi post partum, wierzącemu w bezgrzeszność po chrzcie oraz preferującemu małżeństwo nad dziewictwo. Brak wzmianek o credo nicejskim.

Synod w Mediolanie (390? $)^{94}$ o schizmie w Galii po skazaniu na śmierć Pryscyliana. Brak odniesień do credo nicejskiego.

Synod w Kapui (392) ${ }^{95}$ o schizmie w Antiochii; w sprawie dziewictwa Maryi. Brak odwołań do credo z Nicei.

\footnotetext{
87 Por. Damasus, Lucifer (PL 13, kol. 1131-1147); ŹMT 52, s. 35-43\%.

88 Por. Mansi III, kol. 679-684; ŹMT 52, s. 44-46*.

89 Por. Mansi III, kol. 669.677; ŹMT 52, s. 46-47\%.

90 Por. Mansi III, kol. 691-698; 52, s. 47-47\%.

91 Por. Mansi III, kol. 691-698; ŹMT 52, s. 47-52\%.

92 Akta synodu w Kartaginie w 390 roku 1, [w:] ŹMT 52, s. 48*: „Pouczyli nas o nich, w określonym porządku, nasi ojcowie, abyśmy tak, jak sami otrzymaliśmy, podobnie ludowi Bożemu wpoili wiarę w Trójcę, którą mamy we władzach naszej [duszy] jako świętość, w jedność Ojca i Syna i Ducha Świętego, która jest nienaruszalna. Wszyscy biskupi rzekli: To właśnie otrzymaliśmy, tak utrzymujemy i tak nauczamy idąc za wiarą apostolską".

93 Por. Mansi III, kol. 663-664; ŹMT 52, s. 53-53*.

94 Por. Mansi III, kol. 664-667; ŹMT 52, s. 53-53\%.

95 Por. Mansi III, kol. 683-686; ŹMT 52, s. 53-56*.
} 
Synod w Cabarsussi (393) ${ }^{96}$, synod donatystów-maksymianistów przeciwko donatyście Primianowi z Kartaginy. Brak wzmianek o credo nicejskim.

Synod w Hipponie (8 października 393 roku) ${ }^{97}$ w sprawach dyscyplinarnych. Brak odwołań do wyznania wiary z Nicei z 325 roku.

Synod w Bagai w Numidii (24 kwietnia 394 roku) ${ }^{98}$, synod donatystów w obronie Primiana, a przeciwko Maksymianowi. Brak wzmianek o credo nicejskim.

Synod w Kartaginie (16 czerwca 394 roku) ${ }^{99}$, na którym ustanowiono delegatów na Synod w Hadrumetum. Brak odniesień do credo nicejskiego.

Synod w Hadrumetum (394) ${ }^{100}$, brak wzmianek o credo z Nicei.

Synod w Nîmes (1 października 396 roku) ${ }^{101}$ w sprawach dyscyplinarnych; przeciwko herezji Pryscyliana oraz schizmie Itacjusza i Feliksa z Trewiru. Brak odniesień do credo nicejskiego.

Synod w Kartaginie (26 czerwca 397 roku) ${ }^{102}$, na którym zabroniono biskupom podróży morskich bez listów polecających metropolity. Brak wzmianek o credo nicejskim.

Synod w Kartaginie (13 i 28 sierpnia 397 roku) ${ }^{103}$, na którym ustalono kanony własne oraz prawdopodobnie Breviarium Hipponense, które rozpoczyna się od zacytowania tekstu credo nicejskiego z 325 roku $^{104}$. Pierwszy Synod, który cytuje pełne brzmienie tekstu credo.

Por. Zeno Veronensis, Optatus (PL 11, kol. 1186-1189); ŹMT 52, s. 57-60*.

Por. Concilia Africae a. 345-525 (Concilia), ed. C. Munier, Turnhout 1974, s. 20-21 (CCL 149); ŹMT 52, s. 60-63*.

Por. Mansi III, kol. 857-858; PL 11, kol. 1189-1191; ŹMT 52, s. 64-66*.

Por. CCL 149, s. 182; ŹMT 52, s. 66-66*.

Por. CCL 149, s. 182; ŹMT 52, s. 66-66*.

Por. Mansi III, kol. 685-686; Concilia Galliae a. 314-506 (Concilia), ed. C. Munier, Turnhout 1963, s. 49-51 (CCL 148); ŹMT 52, s. 69-71*.

Por. Mansi III, kol. 750; ŹMT 52, s. 71-71*.

Por. Mansi III, kol. 875-938; ŹMT 52, s. 71-99*.

Por. Professio fidei de Nicaea (PL 56, kol. 418-419); CCL 149, s. 30-31; Kartagina (III; 13 i 28 VIII 397), II. Nicejskie wyznanie wiary: „Odczytano i zatwierdzono wyznanie 
Synod w Turynie (22 września 398 roku $)^{105}$ o władzy biskupów po cywilnym tworzeniu nowych prowincji dla Galii. Brak formalnych odniesień do wyznania wiary z Nicei.

Synod w Kartaginie (27 kwietnia 399 roku ${ }^{106}$ o prawie azylu w kościołach. Brak wzmianek o credo nicejskim.

W kościelnych zbiorach prawnych IV wieku dla lat 325-399 znajdujemy wzmianki i akta 59 Synodów zachodnich. Istnienie trzech z nich wydaje się dziś nieautentyczne (tj. synod w Rzymie z 325 roku; synod w Ilirii z 378 roku i synod w Mediolanie z 381 roku). W interesującym nas przedziale czasowym odbyło się zatem 56 synodów lokalnych, które mogły ustosunkować się do credo soborowego z 325 roku. W aktach i fragmentach prawnych zachowanych z tych obrad kościelnych można wyróżnić kilka typów odwołań do credo nicejskiego. Są to wzmianki:

- pośrednie negatywne - pojawiająe się 3 razy (mowa o potępieniu przez arian uchwał Soboru Nicejskiego - Synod w Rzymie z lat 340-341; dekret odrzucający nicejskie sformułowanie „współistotny" - Synod ariański w Sirmium z 357 roku; dekret potępiający użycie nicejskiego terminu ovøı - Synod ariański w Sirmium z maja 359 roku);

- pośrednie pozytywne - pojawiające się 4 razy (powołanie się na credo nicejskie przy potępieniu Eustatiosa z Sebasty za negowanie współistotności Ojca i Syna - Synod w Rzymie z 374 roku;

wiary przyjęte podczas synodu w Nicei, w brzmieniu: Wierzymy w jednego Boga Ojca wszechmogącego, stworzyciela rzeczy widzialnych i niewidzialnych i w jednego Pana Jezusa Chrystusa, Syna Bożego, zrodzonego z Ojca, jednorodzonego, to jest z substancji Ojca, Boga z Boga, światłość ze światłości, Boga prawdziwego z Boga prawdziwego, zrodzonego, niestworzonego, jednej substancji z Ojcem, co Grecy wyrażają omousion; przez niego wszystko powstało, czy to w niebie, czy to na ziemi; on to dla nas ludzi i dla naszego zbawienia zstąpił [z nieba], przyjął ciało, stał się człowiekiem poprzez Dziewicę Maryję; cierpiał i zmartwychwstał trzeciego dnia, wstąpił do nieba, przyjdzie sądzić żywych i umarłych. I w Ducha Świętego. Tych, którzy mówią: było, kiedy [Go] nie było; zanim się narodził nie istniał; oraz: ponieważ powstał z nicości lub z innej substancji, mówią, że Syn Boży jest zmienny i przeobrażany, tych Kościół katolicki i nauka apostolska anatematyzuje". ŹMT 52, s. 72-73*.

105 Por. Mansi III, kol. 859-866; ŹMT 52, s. 99-101*.

106 Por. Mansi III, kol. 750; ŹMT 52, s. 102-102*. 
powołanie się na credo nicejskie przy anatematyzmach Tomus Damiani - Synod w Rzymie z lat 376-377; potwierdzenie credo z Nicei przy potępieniu arian Palladiusza i Sekundiana - Synod w Akwilei z 381 roku; ogólne powołanie się na treść credo nicejskiego - Synod w Kartaginie z 390 roku)

- bezpośrednie nieformalne - pojawiające się 1 raz (opowiedzenie się za nicejską formułą wiary w pierwszej fazie synodu, lecz ostatecznie pod naciskiem cesarza Konstancjusza II formalne podpisanie ariańskiej formuły z Nike z 359 roku - Synod w Rimini z maja-października 359 roku);

- bezpośrednie formalne - pojawiające się 5 razy (odwołanie się do treści credo soborowego i przyjęcie nicejskich terminów: „współistotny”, ovøı - „substancja” - Synod w Paryżu z lat 360-361; odwołanie się do tekstu credo, włączenie go do akt synodalnych i określenie go jako katolickie, apostolskie, obowiązujące - Synod w Rimini z lat 365-366; potwierdzenie credo nicejskiego - Synod na Sycylii z 366 roku; powołanie się na credo z Nicei jako apostolskie i będące odtrutką na arianizm - Synod w Rzymie, około 370 roku; pełne zacytowanie tekstu credo w aktach Breviarium Hipponense - Synod w Kartaginie z 397 roku).

W latach 325-399 na 56 autentycznych synodów Kościoła zachodniego spotykamy więc w ich aktach 13 odwołań do credo nicejskiego: trzy pośrednie negatywne, cztery pośrednie pozytywne, jedno bezpośrednie, lecz nieformalne, i pięć bezpośrednich formalnych. Chronologicznie pierwszą jest wzmianka pośrednia negatywna z Synodu w Rzymie z lat 340-341 (o potępieniu przez arian uchwał Soboru Nicejskiego). Chronologicznie pierwszą wzmianką bezpośrednią, lecz wyrażoną w sposób nieformalny jest wstępne opowiedzenie się za nicejską formułą wiary w pierwszej fazie synodu w Rimini z 359 roku. Pierwszym bezpośrednim i formalnym odwołaniem się do treści credo nicejskiego są akta Synodu w Paryżu z lat 360-361. Natomiast pierwsze cytowanie pełnego tekstu credo $\mathrm{w}$ aktach synodalnych miało miejsce na synodzie w Kartaginie w 397 roku. W zachodnich aktach synodalnych w latach 40. i 50. IV wieku w stosunku do credo nicejskiego przeważają odniesienia pośrednie negatywne, natomiast w latach 60. i 70. IV wieku następuje przewaga odniesień bezpośrednich i formalnych. Czy ta powolna akceptacja nicejskiego wyznania wiary z 325 roku, jaka wyraźnie następuje od lat 60 . IV wieku, miała w Kościele zachodnim jakiś bardziej praktyczny wymiar? Wydaje się, że nie... 
Credo ułożone na Soborze Nicejskim I w 325 roku, mimo pozytywnej recepcji synodalnej, tak na Wschodzie, jak i na Zachodzie nie znalazło większego zastosowania w kościelnym użyciu. Nie spotykamy w IV wieku na Zachodzie żadnego Kościoła lokalnego, który stosowałby credo nicejskie w swej liturgii. W Kościołach partykularnych nadal stosowano bowiem chrzcielne wyznania wiary ${ }^{107}$. Mario Righetti ${ }^{108}$, powołując się na historyka bizantyjskiego Teodora Lektora ${ }^{109}$, podaje, że pierwszym, który wprowadził do liturgii chrześcijańskiej zwyczaj odmawiania credo konstantynopolitańskiego, propagowanego wtedy jako ułożone w duchu credo nicejskiego, był Tymoteusz, monofizycki patriarcha Konstantynopola. Miał on zarządzić około 515 roku, że po pocałunku pokoju, a przed rozpoczęciem recytowania anafory, wszyscy w kościele będą odmawiać symbol wiary. Praktyka ta rozprzestrzeniła się najpierw na Wschodzie, następnie została usankcjonowana przez cesarza Justyna II w 568 roku. Na Zachodzie zwyczaj odmawiania credo soborowego wprowadzili najpierw już katoliccy Wizygoci (uchwała III Synodu w Toledo z 589 roku): „secundum formam orientalium Ecclesiarum"110. W praktyce liturgicznej Kościoła wizygockiego fraza credo konstantynopolitańskiego odnosząca się do Ducha Świętego - „ex Patre procedentem” - została jednak zmieniona na „ex Patre et Filio procedentem”. Fraza ta została zaakceptowana przez kolejne Synody toledańskie jako ortodoksyjna, lecz jej wprowadzenie do tekstu credo konstantynopolitańskiego było wyraźnie arbitralne ${ }^{111}$.

107 Por. L. Ayres, Nicea and its legacy. An approach to fourth-century trinitarian theology, New York 2004, s. 85-88.

108 Por. M. Righetti, Manuale di storia liturgica, vol. III, dz. cyt., s. 294-296.

109 Teodor Lektor, Historia ecclesiastica fragm. II,32, [w:] Liturgica Mozarabica, vol. 2 (PG 86, kol. 202).

110 J. D. Mansi, Sacrorum conciliorum nova et amplissima collectio, vol. IX, Ab anno 536 usque ad annum 590 inclusive [dalej: Mansi IX], Florentiae 1763, kol. 983.

111 Kwestię użycia liturgicznego formuły Filioque w credo konstantynopolitańskim upowszechnił cesarz Karol Wielki, kiedy zwołał Synod we Frankfurcie w 794. Występując przeciw kultowi obrazów zaakceptowanemu przez Sobór Nicejski II z 787 roku biskupi frankońscy potępili patriarchę Taraziosa, proklamowali Filioque jako naukę katolicką i nakazali ją śpiewać podczas niedzielnej mszy św., poczynając od kaplicy cesarskiej. Papież Leon II nie zganił użycia Filioque w credo konstantynopolitańskim, a papież Leon III uznał ostatecznie ortodoksyjność Filioque, choć nie zgodził się na 
Na przełomie VII i VIII wieku, pod wpływem liturgii wizygockiej, credo konstantynopolitańskie zostało wprowadzone najpierw do Ordo missae liturgii celtyckiej. Z Irlandii zwyczaj recytowania credo konstantynopolitańskiego, ale już z dodaniem Filioque do oryginalnego tekstu tego wyznania (Synod we Frankfurcie z 794 roku), wszedł także do liturgii galijskiej (Alcuin), liturgii akwilejskiej (biskup Paulin z Aquilei, Synod w Cividale del Friuli z 796 roku) ${ }^{112}$.

Jeszcze na początku XI wieku Kościół w Rzymie nie używał symbolu konstantynopolitańskiego podczas celebracji eucharystycznej. Charakterystyczny w tej kwestii był dialog pomiędzy papieżem Benedyktem VIII (1012-1024) a cesarzem Henrykiem II (973/9781024) podczas koronacji tego ostatniego dnia 14 lutego 1014 roku. Jak odnotował naoczny świadek Bernon z Reichenau OSB (zm. 1048) ) $^{113}$, na zdziwienie cesarza, iż w Rzymie nie słychać symbolu podczas celebracji mszy, w przeciwieństwie do Kościołów Północy, papież miał odpowiedzieć, że Kościół rzymski nie czuł potrzeby dodawania takiego zwyczaju, ponieważ nigdy nie był zarażony herezją... Jednak chcąc wyjść naprzeciw pragnieniu cesarza, papież zarządził, aby włączyć zwyczaj odmawiania credo konstantynopolitańskiego do rytuału mszy św. uroczystych. Jednak niedługo po tym zarządzeniu Benedykt VIII wydał sprostowanie, w którym zarządził stosowanie wspomnianego credo jedynie podczas najważniejszych świąt. Ostatecznie do liturgii rzymskiej zwyczaj odmawiania credo konstantynopolitańskiego z dodatkiem Filioque został wprowadzony dopiero na początku XII wieku' ${ }^{114}$.

wprowadzenie go do credo rzymskiego. Uczynił to dopiero papież Benedykt VIII w 1014 roku, a dogmatycznie usankcjonował Sobór Lyoński w 1274. Natomiast Kościół prawosławny uznał oficjalnie formułę Filioque za herezję w encyklice czterech patriarchów z 1848 roku. Por. R. Laurentin, Nieznany Duch Święty. Odkrywanie Jego doświadczenia i Jego osoby, tłum. M. Tarnowska, Kraków 1998, s. 363; H. Paprocki, Problem „Filioque”, [w:] Duch, który jednoczy. Zarys pneumatologii. Praca zbiorowa, red. M. Marczewski, Lublin 1998, s. 160.

Por. M. Righetti, Manuale di storia liturgica, vol. III, dz. cyt., s. 295-296.

113 Por. Bernon z Reichenau vel Berno Augiensis, Libellus de quibusdam rebus ad missae officium pertinentibus II (PL 142, kol. 1060-1061).

114 Por. M. Righetti, Manuale di storia liturgica, vol. III, dz. cyt., s. 297; Ordo officiorum ecclesiae lateranensis: Bernardi cardinalis et lateranensis ecclesiae prioris 6, ed. L. Fischer, Münich 1916, s. 3: „ "Credo in unum» cantamus omnibus dominicis et praecipuis festis". 


\section{Wnioski}

Recepcja credo nicejskiego zarówno w Kościele wschodnim, jak i zachodnim w IV wieku dokonywała się bardzo powoli. Najstarszy grecki zbiór prawa kanonicznego na Wschodzie zawierający tekst credo nicejskiego to Corpus Canonum, powstały w dwóch fazach, obejmujących lata 361-376 i 381-451. W stosunku do pierwszych świadków tekstu credo nicejskiego na Wschodzie (Euzebiusz z Cezarei, List do swego Kościoła 8, ok. 325 roku; Atanazy z Aleksandrii, O dekretach Soboru Nicejskiego, ok. 345/359) zbiory prawne są późniejsze o około 30 lat. Niezależnie od uchwał synodalnych, z czasem coraz bardziej pozytywnych wobec uchwał Nicei z 325 roku, recepcja tego credo w Kościele wschodnim była słaba: żaden Kościół lokalny nie używał tego wyznania wiary, a Kościoły partykularne posługiwały się nadal własnymi chrzcielnymi wersjami credo. Taka sytuacja miała miejsce także po synodzie w Konstantynopolu w 381 roku.

Analogiczna sytuacja miała miejsce w Kościele zachodnim w IV wieku. Według kryterium autentyczności na 56 synodów lokalnych odbytych na Zachodzie w IV wieku w przedziale czasowym 325-399 spotykamy jedynie 13 odwołań do credo nicejskiego (trzy pośrednie negatywne, cztery pośrednie pozytywne, jedno bezpośrednie nieformalne, pięć bezpośrednich formalnych). Wyraźnie można zaobserwować, że odniesienia bezpośrednie i formalne mają miejsce dopiero od lat 60. IV wieku. Pomimo pozytywnego odbioru tego symbolu wiary na późniejszych synodach zachodnich credo nicejskie nie znalazło jakiegokolwiek zastosowania w Kościele zachodnim w IV wieku i później. Pierwsze użycie liturgiczne credo konstantynopolitańskiego z 381 roku na Zachodzie odnajdujemy dopiero w drugiej połowie VI wieku w liturgii wizygockiej. Wprowadzenie tego credo na Zachodzie w VI wieku pokrywa się z bizantyjską promocją credo konstantynopolitańskiego, uznawanego według argumentacji przyjętej na soborze w Chalcedonie jako przedłużenie credo nicejskiego. Nie powinien zatem dziwić fakt, że liturgia rzymska wprowadza credo konstantynopolitańskie z 381 roku (ale już z dodatkiem Filioque) dopiero na początku XII wieku.

Przedstawiony powyżej brak jakiegokolwiek zastosowania credo nicejskim w Kościele na Zachodzie w IV wieku uwiarygadnia opinię H. Pietrasa o celowym fałszerstwie i wymuszeniu na Rzymie uznania dla Konstantynopola. Co ciekawe, upowszechniana od 381 roku 
przez Konstantynopol teza o przewodniej roli tegoż Kościoła, powtórzona następnie przez Sobór w Chalcedonie w 451 roku, nie znalazła uznania na Zachodzie aż do końca V wieku. Po praktycznym odrzuceniu credo nicejskiego Konstantynopol zaczął od VI wieku upowszechniać credo z Konstantynopola z 381 roku jako przedłużenie credo nicejskiego. Jak wynika $\mathrm{z}$ historii, promocja się udała, Synod z Konstantynopola z 381 roku określamy dziś w historiografii jako Sobór, a ustanowione tam credo jako "nicejsko-konstantynopolitańskie".

\section{Summary}

\section{The reception of Nicene Creed in the IV ${ }^{\text {th }}$ century teaching of the Western Church}

The Nicene Creed have been implemented very slowly in the West and in the East Church as well. This creed has not been applied in the Eastern Church, even though it was promulgated by the ecumenical conceals. Eastern particular Churches still used their own version of the baptismal creed. The same situation was in the West. 56 local synods were gathered between 325 and 399 . However, we have only 13 references to the Nicene Creed (three times indirectly negative, four times indirectly positive, once directly informal and five times directly formal). The direct and formal references appeared not until the 460's. The very first liturgical application of the Constantinopolitan Creed (381) dated from the Visigothic liturgy (the second half of the sixth century). At the same time the Constantinopolitan Creed has been implemented in the Church of Byzantine Empire, where it was regarded as a continuation of Nicene Creed according to the Chalcedonian arrangements. Uncontestable fact that, the Nicene Creed was not applied in the Western Church in the fourth century, confirms Henryk Pietras' thesis that the Constantinople Church couldn't play any leading role in the fourth century Christianity. The Creed promulgated by First Ecumenical Council (325) was practically rejected in the West. The Constantinople Council (381) began to popularise an amplified and approved form of the Christian Faith as the Nicene-Constantinopolitan Creed. The Council of Chalcedon (451) reaffirmed that symbol an designated it as "The Creed of the Council of Constantinople of 381". Gradually it came to be recognized as normative one.

Keywords: IV ${ }^{\text {th }}$ century, Western Church, Nicene Creed, reception 


\section{Bibliografia}

Ambrosius Mediolaniensis, Epistolae Prima Classis (Patrologia Latina, ed. J. P. Migne, Paris 1844-1855, t. 16, kol. 850-1220).

Ambrosius Mediolaniensis, Epistolae Secunda Classis (Patrologia Latina, ed. J. P. Migne, Paris 1844-1855, t. 16, kol. 1220-1286).

Ambroży z Mediolanu, Epistula, ed. O. Faller, M. Zelzer, Wien 1968-1996 (Corpus Scriptorum Ecclesiasticorum Latinorum, 82/1).

Anatolis K., Retrieving Nicaea: the development and meaning of trinitarian doctrine, Grand Rapids 2011.

Arianism: historical and theological reassessments: papers from the Ninth International Conference on Patristic Studies, September 5-10, 1983, Oxford, England, Eugene 2006.

Atanazy z Aleksandrii, De decretis Nicaenae synodi, [w:] Athanasius (Patrologia Latina, ed. J. P. Migne, Paris 1844-1855, t. 25b, kol. 416-476); tłum. polskie: O dekretach Soboru Nicejskiego, tłum. P. M. Szewczyk, Kraków 2011, s. 1-33 (Źródła Myśli Teologicznej, 60).

Augustinus, De Trinitate, ed. W. J. Mountain, F. Glorie, Turnhout 1968 (Corpus Christianorum. Series Latina, 50A).

Augustyn z Hippony, Epistolae I/2 (71-123) (Nuova Biblioteca Agostiniana, XXI/2). Testo latino dall 'edizione maurina confrntato con il Corpus Scriptorum Ecclesiasticorum Latinorum, editore L. Carrozzi, Roma 1992, wyd. II, s. 806-877.

Ayres L., Nicea and its legacy. An approach to fourth-century trinitarian theology, New York 2004.

Behr J., The Nicene faith: formation of Christian theology, vol. 2, New York 2004.

Bernon z Reichenau vel Berno Augiensis, Libellus de quibusdam rebus ad missae officium pertinentibus (Patrologia Latina, ed. J. P. Migne, Paris 1844-1855, t. 142, kol. 1055-1080).

Borchardt C. F. A., Hilary of Poitiers' role in the Arian struggle, Hague 1966 (Kerkhistorische Studien Behorende bij het Nederlands Archief voor Kerkgeschiedenis, 12).

Bralewski S., Cesarz Konstantyn I Wielki wobec kontrowersji ariańskiej, Poznań 2009 (Labarum, VIII).

Brennecke H. Ch., Hilarius von Poitiers und die Bischofsopposition gegen Konstantius II: Untersuchungen zur dritten Phase des Arianischen Streites (337-361), Berlin 1984 (Patristische Texte und Studien, 26).

Camelot P. Th., Creeds, [w:] Sacramentum mundi. An encyclopedia of theology, ed. K. Rahner, C. Ernst, K. Smyth, t. 2, London $1973^{5}$, s. 37-40.

Concilia Africae a. 345-525 (Concilia), ed. C. Munier, Turnhout 1974 (Corpus Christianorum. Series Latina, 149). 
Concilia Galliae a. 314-506 (Concilia), ed. C. Munier, Turnhout 1963 (Corpus Christianorum. Series Latina, 148).

Damasus, Lucifer (Patrologia Latina, ed. J. P. Migne, Paris 1844-1855, t. 13).

Dokumenty Soborów Powszechnych, tekst grecki, łaciński, polski, red. A. Baron, H. Pietras, t. 1, 325-787, Kraków 2001 (Źródła Myśli Teologicznej, 24).

Dokumenty synodów od 50 do 381 roku, red. A. Baron, H. Pietras, Kraków 2006 (Źródła Myśli Teologicznej, 37).

Dokumenty synodów od 381 do 431 roku, red. A. Baron, H. Pietras, Kraków 2010 (Źródła Myśli Teologicznej, 52).

Dossetti G. L., Il simbolo di Nicea e di Costantinopolo: edizione critica, Roma-Freiburg-Basel 1967.

Eusebii Caesariensis epistola ad suae parociae homines (Patrologia Graeca, ed. J. P. Migne, Paris 1857-1866, t. 20, kol. 1535-1544); tłum. polskie: List Euzebiusza z Cezarei do swego Kościoła, [w:] Dokumenty Soborów Powszechnych, tekst grecki, łaciński, polski, red. A. Baron, H. Pietras, t. 1, 325-787, Kraków 2001, s. 56-57 (Źródła Myśli Teologicznej, 24).

Gaudemet J., Conciles gaulois du IVe siécle, Paris 1977 (Sources Chrétiennes, 241).

Gliściński J., Wspótistotny Ojcu, Łódź 1992.

Hanson R. P. C., The search for the Christian doctrine of God. The arian controversy, Grand Rapids 2007.

Hilarius Pictaviensis, Tractatus mysteriorum, Fragmenta, Ad Constantium Imperatorem, Hymni; Pseudo-Hilarius, Epistula ad Abram filiam, Hymni, ed. A. Feder, WienLeipzig 1916, kol. 95-96 (Corpus Scriptorum Ecclesiasticorum Latinorum, 65)

Hilary z Poitiers, De synodis seu de fide Orientalium (Patrologia Latina, ed. J. P. Migne, Paris 1844-1855, t. 10, kol. 479-546).

Laurentin R., Nieznany Duch Święty. Odkrywanie Jego doświadczenia i Jego osoby, tłum. M. Tarnowska, Kraków 1998.

Mansi J. D., Sacrorum conciliorum nova et amplissima colectio, vol. II, Ab anno 305 ad annum 346, Paris 1901.

Mansi J. D., Sacrorum conciliorum nova et amplissima colectio, vol. III, Ab anno 347 ad annum 409, Florentiae 1759.

Mansi J. D., Sacrorum conciliorum nova et amplissima collectio, vol. IX, Ab anno 536 usque ad annum 590 inclusive, Florentiae 1763.

Ordo officiorum ecclesiae lateranensis: Bernardi cardinalis et lateranensis ecclesiae prioris, ed. L. Fischer, Münich 1916.

Paprocki H., Problem „Filioque”, [w:] Duch, który jednoczy. Zarys pneumatologii. Praca zbiorowa, red. M. Marczewski, Lublin 1998, s. 150-182.

Pietras H., Sobór nicejski (325). Kontekst religijny i polityczny, dokumenty, komentarze, Kraków 2013. 
Pietras H., Spór o wyznanie wiary w IV wieku, „Teologia Patrystyczna” 2007 nr 4, s. 35-50.

Righetti M., Manuale di storia liturgica, vol. III, L'Eucaresita. Sacrificio e sacramento, Milano 1998.

Simonetti M., La crisi ariana nel IV secolo, Roma 1975 (Studia Ephemeridis Augustinianum, 11).

Simonetti M., Studi di cristologia postnicena, Roma 2006 (Studia Ephemeridis Augustinianum, 98).

Szewczyk P. M., Wprowadzenie, [w:] O dekretach Soboru Nicejskiego, tłum. P. M. Szewczyk, Kraków 2011, s. 1-33 (Źródła Myśli Teologicznej, 60).

Teodor Lektor, Historia ecclesiastica fragm., [w:] Liturgica Mozarabica, vol. 2 (Patrologia Graeca, ed. J. P. Migne, Paris 1857-1866, t. 86, kol. 165-228).

Ulrich J., Die Anfänge der Abendländischen Rezeption des Nizänums, Berlin 1994 (Patristische Texte und Studien, 39).

Williams D. H., The anti-Arian campaigns of Hilary of Poitiers and the „Liber Contra Auxentium”, "Church History” 1992 nr 1 (61), s. 7-22.

Williams R., Arius: heresy and tradition, Grand Rapids 2002.

Zeno Veronensis, Optatus (Patrologia Latina, ed. J. P. Migne, Paris 1844-1855, t. 11). 